\title{
Microplate Reader
}

National Cancer Institute

\section{Source}

National Cancer Institute. Microplate Reader. NCI Thesaurus. Code C70661.

An instrument for the automated determination of absorbance data from multiple samples contained in a microplate. 